http://artnodes.uoc.edu

ARTICLE

NODE: «ART MATTERS»

\title{
Artistic Practices, Discursive Contexts and Environmental Humanities in the Age of the Anthropocene
}

\author{
Christian Alonso \\ Research group Art Globalization Interculturality (AGI) \\ Department of Art History \\ University of Barcelona
}

Submission date: April 2015

Accepted date: May 2015

Published in: June 2015

\begin{abstract}
The hypothesis of the Anthropocene signals human activity, particularly the social, political and economic sphere, as the new biogeophysical force whose impact allows the scientific community to speak about a new era in the geological time-scale. The assertion of the abandonment of the Holocene implies not only access to a new physical, but also a cultural space that has not yet been experienced. However, while contributions from the field of natural sciences to the analysis of the phenomenon have been significant, literature generated from the Humanities and Social Sciences shows that much work remains to be done. In this current scenario where increased global connectivity operates as the ground for interconnected large-scale risks and shocks, we are compelled to take into account transversal thinking across different ideas, meanings and fields that can help understanding the social, the economic and the political relations at stake.

Drawing from recent investigations from the field of Environmental Humanities, this paper explores the role of artistic, theoretical and curatorial practice in understanding, conforming and interrogating our position in the world under the conditions of the Anthropocene. It shall do this by focusing on the analysis of projects gathered in the group exhibition 7 MIL MILLONES (EACC Castelló, 2014) as a case study. We argue that experimental artistic practice - which emphasizes a new combination of aesthetics and ethics and the ecological and the social - can provide interesting models in helping societies adapt to this new territory. We finally suggest that the curatorial statement fails to address the complex critical potential of the gathered projects insofar as it constrains the theoretical context to a particular classical formulation
\end{abstract}




\section{artnodes}

http://artnodes.uoc.edu

Artistic Practices, Discursive Contexts and Environmental Humanities...

of sustainable development and an omission of their consideration as artifacts for political imagination.

\section{Keywords}

anthropocene societies, ecosophy, sustainability, cultural ecology, environmental aesthetics, postcolonial environmentalism

\section{Prácticas artísticas, contextos discursivos y humanidades medioambientales en la época del antropoceno}

\section{Resumen}

La hipótesis del antropoceno señala la actividad humana, particularmente la esfera social, política y económica, como la nueva fuerza biogeofísica cuyo impacto permite a la comunidad científica hablar de una nueva época en la escala temporal geológica. La afirmación del abandono del Holoceno no solo implica el acceso a un nuevo espacio físico sino también a un nuevo espacio cultural que todavía no ha sido experimentado. A pesar de que las contribuciones del campo de las ciencias naturales al análisis del fenómeno han sido significativas, la literatura generada por las humanidades y las ciencias sociales demuestra que aún queda mucho por hacer. En el actual escenario en el que una creciente conectividad global con frecuencia se traduce en la emergencia de riesgos e impactos interconectados a gran escala, se impone la necesidad de adoptar un pensamiento transversal que al abarcar diferentes ideas, significados y campos, nos pueda ayudar a entender las relaciones sociales, económicas y políticas que estan en juego. Partiendo de recientes investigaciones realizadas en los campos de las humanidades medioambientales, este trabajo explora el papel de la práctica artística, teórica y curatorial en el entendimiento, la conformación e interrogación de nuestra posición en el mundo bajo las condiciones del Antropoceno. Para ello nos centraremos en el análisis de los proyectos reunidos en la exposición colectiva 7MIL MILLONES (EACC, Castelló, 2014) como casos de estudio. Argumentamos que la práctica artística experimental que enfatiza una nueva combinación de la estética y la ética con lo ecológico y lo social, puede ofrecernos interesantes modelos que ayuden a las sociedades a adaptarse a este nuevo territorio. Para finalizar, sugerimos que el proyecto curatorial de los comisarios no consigue abordar la complejidad ni captar el potencial crítico de los proyectos presentados en la medida en que restringe el contexto teórico a una clásica formulación del desarrollo sostenible al tiempo que omite su consideración como artefactos para la imaginación política.

\section{Palabras clave}

sociedades del Antropoceno, ecosofía, sostenibilidad, ecología cultural, estética medioambiental, ambientalismo poscolonial 


\section{artnodes}

\section{The Anthropocene described by natural scientists}

One can observe an increased awareness of the human impact on ecosystems or, to put it differently, of the shift from a global system dominated by nature to a world dominated by humans. In the field of natural sciences, this impact has been described from late 18th century as the "antropozoic era" proposed by Italian geologist Stoppani, later as 'noosphere', 'anthroposphere' and recently major efforts have been taken place in order to reach a consensus in formalizing the thesis of the Anthropocene (Steffen et al., 2011). Developed by Paul Crutzen and Eugene Stoermer, the hypothesis of the Anthropocene signals human activity as the new biogeophysiscal force whose impact allows the scientific community to speak about a new era in the geological time-scale.

The environmental turn which this thesis describes has been analyzed in terms of scale and magnitude of ocean alteration, transformations in earth biosphere, carbon dioxide concentrations in the atmosphere, and raising temperatures (Zalasiewicz et al., 2011). ${ }^{1}$ The presence of this data has even allowed scientists to formulate a stratigraphy of the Anthropocene. Crutzen places the beginning of this new geological era at the end of the 18th century and as being primarily caused by the effect of burning fossil fuels in the atmosphere on a global scale. According to theory, a more severe second phase of the Anthopocene known as "The Great Acceleration" - characterized by key factors as increased world population, the implementation of neo-liberal economic systems, atomic testing, and a dramatic increase of carbon dioxide levels has taken place from Second World War up to now (Steffen et al., 2011, pp. 849-853).

In either case, the most relevant point is that this theory assigns human impact at least as much importance and force as the main natural forces - solar influence, volcanic activity, extraterrestrial asteroid impacts and natural selection - in terms of responsibility for global environmental change. The theory identifies a multiplicity of evidences that support the presumption of the abandonment of the Holocene, the previous interglacial epoch that emerged 11,784 years ago. This level of human imprint has been similarly identified in the fields of ecology and biology in shaping the so-called humandominated habitats and "novel ecosystems". ${ }^{2}$ They argue that natural and human-influenced systems cannot be conceived as separate anymore (Corlett, 2014, pp. 36-41).

\section{The need for interdisciplinary approach within Humanities and Social Sciences}

Climate breakdown, however, comes paired with no less urgent questions that exceed the natural sciences disciplinary boundaries. Indeed, the Anthropocene describes an environmental turn that coexists with energetic, financial-systemic, food and humanitarian crises. In fact, what is more striking is that this hypothesis points to human behaviour, particularly the social, political and economic sphere as the main driver of the change. However, whereas contributions from the field of Natural Sciences have been significant, relevant literature generated from the Humanities and Social Sciences remains proportionately lacking. In order to tackle this urgent task, human scientists will have to ask themselves, as theoretician Tobias Boes does, how can we experience ourselves as a species having geophysical and biochemical impact upon the planet? Certainly, as Boes notes, what we desperately need "are a set of hermeneutics and poetics (a theory of understanding and a theory of expression) that might accompany the scientific study of the changing Earth system" (Boes, 2014, p. 168).

The article "Reconceptualizing the 'Anthropos' in the Anthropocene: Integrating the Social Sciences and Humanities in Global Environmental Change Research" (Palsson, 2012) is perhaps the most systematic up-to-date study on contributions made from the Human and Social Sciences to the analysis of the emergent questions which arise in the age of Anthropocene. This text attempts to relocate as well as redefine the decentred human being - in the sense of its separateness from nature - in a map from which it was once erased by humanist ideology. The study provides a genealogy of contributions to the discussion and takes steps to draft a program for research within the Humanities and Social Sciences that can help us face these urgent individual and collective challenges.

The first mental disposition from this approach would consist of understanding the environment as a social category. Secondly, planetary boundaries - comprised by loss of biodiversity, the effect of nitrogen and phosphorous cycle, climate crisis, ocean acidification, chemical and particle atmospheric pollution, deforestation and freshwater use - must be directly linked to the human experience, and must be placed in a more specific frame that includes notions of distribution, geography, equity, and a consideration of the environmental effects on humans in a local / global context. Thirdly, we must individually and collectively articulate societies of the

1. The term was coined by Nobel Prize on Atmospheric Chemistry Paul Crutzen in 2002. Since then the hypothesis about a new global era has been debated firstly from the field of geology and more specifically from a group of researchers working in the context of The Royal Society in London

2. Novel ecosystems is "a unique assemblage of biota and environmental conditions that are the direct result of intentional or unintentional alteration by humans, i.e., human agency, sufficient to cross an ecological threshold that facilitates a new ecosystem trajectory and inhibits its return to a previous trajectory regardless of additional human intervention". Novel ecosystems are thus human-built niches of the Anthopocene and include technosols, technodiversity, anthromes and technosphere. 


\section{artnodes}

http://artnodes.uoc.edu

Antropocene on the basis of a reformulated linkage with democracy, promoting a new combination of the natural and the ideal in an interdisciplinary way, and transforming contemporary syndromes of anxiety in a more positive task of attempting to construct a culture of sustainability. This would be implemented in the search of new technologies, medical knowledge, and new ideas about social and economic models. Finally, we must explore diverse ways in which western thought can confront its limits in order to adapt to the new condition of the Anthropocene, overcoming the polarization of nature and culture (Palsson et al., 2012, p. 11).

This research primarily expresses a whole new way of reading the world: one that is based on systemic thinking that focuses on the flow of things and thoughts in the analysis of interactions between material and cultural processes; an ontological and epistemological project that investigates the so-called "ecological interdependency" from the fields of anthropology, linguistics, sociology, philosophy and psychology, and more specifically from the domain of systems theory, psycoanalysis, sociology of science and speculative realism (Bateson, 1972; Guattari, 1989; Latour, 2004; Timothy Morton, 2004). It contributes to a fruitful body of theory that can be considered as a sort of "anthropogenic ecosophy" that traces a mesh of unseen connections between climate science, ecology, politics, economy, international institutions and global governance in the understanding of the novel, global and fluid risks posed by the Anthropocene.

\section{The role of artistic practice}

From the field of artistic practice and visual culture, a great number of projects that reflect on the new condition of Anthropocene societies have emerged in recent years focusing on a new combination of aesthetics and ethics, the ecological and the social, suggesting new considerations between the human and non-human as well as objects and experiences. Recognizing the limits of artistic representation of the Anthropocene - equally ungraspable as it is for natural scientists in demarcating its actors - one finds that these projects provide a sensory experience of a new way of thinking and inhabiting the world. Within the field of art history and cultural theory, the analysis of the role of this sort of politico-ecological aesthetics within the parameters of this new space have been anticipated by
Artistic Practices, Discursive Contexts and Environmental Humanities...

T.J. Demos in his writings about contemporary art and the politics of ecology (Demos, 2014, 2013, 2012, 2009). Demos provide a fecund theoretical and critical framework that helps in analyzing the emerging field of art practice related to the Anthropocene through the identification of an overarching criteria as well as the critical positions of the projects: "broadly speaking, then, the present and ongoing challenge is to reunite a critical environmentalism with an ecologically attendant postcolonialism, engendering a political ecology based on the commitment to environmental sustainability, biodiversity, social justice, human rights, economic equality and democratic practice" (Demos, 2013, p. 7). These critical bases which acknowledge the legacy of Félix Guattari's "Ecosophy", Bruno Latour's "Politics of Nature", Neil Smith's Cultural Geography and Vandana Shiva's postcolonialism and rights-of-nature approachoffer a fertile ground from which to address the complexity of the artistic and curatorial practices that ponder the challenges of the Anthropocene.

The proliferation of these practices is expressed in the great number of exhibitions focusing on the theme. Among the most prominent we can highlight those that reflect on the interrelated social, political and economic links that define the very notion of the Anthropocene which help visualize the relations of the systemic thinking it invokes, such as The Anthropocene (Deustches Museum, München, 2013-14) ${ }^{3}$ The Anthropocene Observatory (Haus der Kulturen der Welt, Berlin, 2013-14) ${ }^{4}$ or Systémique - Think global, act local (CEAAC Strasbourg, 2015). ${ }^{5}$

Others revolve around the current social, political and cultural crises, and the relation between humans and non-humans through the works and the initiatives of artists, political activists and indigenous people, such as Rights of Nature. Arts and Ecology in the Americas (Nottingham Contemporary, United Kingdom, 2015). ${ }^{6}$ Whereas others show collaborative practices with which to physically transform ecologies and politics creatively, such as Ecovention: Current Art to Transform Ecologies, ${ }^{7}$ or Groundworks: Environmental Collaboration in Contemporary Art. ${ }^{8}$ Others develop strategies related to recycling, communitarian activism, research on new sustainable fuels and alternative land used through industrial design, such as Beyond Green: Toward a Sustainable Art (Chicago, 2005). ${ }^{9}$ Others explore the complex and changing relationship of humans with the natural world by analyzing the political dimensions, for example Like a Bird:

3. This exhibition was curated by Nina Möllers.

4. A project by Armin Linke, Territorial Agency (John Palmesino and Ann-Sofi Rönnskog) and Anselm Franke developed in the context of the Anthopocene Project taking place at Haus der Kulturen der Welt (2013-2014).

5. Curated by Lauranne Germond and Loïc Fel (COAL).

6. Curated by T.J. Demos.

7. Hosted at Cincinatti Contemporary Arts Center, curated by Sue Spaid. See <http://greenmuseum.org/c/ecovention/intro_frame.html>.

8. Hosted at Regina Miller Galley, Mellon University (Pittsburg, USA) and curated by Grant Kestner.

9. Curated by Stephanie Smith at the Chicago Smart Museum of Art. 


\section{artnodes}

http://artnodes.uoc.edu

Avian Ecologies in Contemporary Art (Tranzit.ro Gallery, Romania, 2014) $)^{10}$ and Live Forms, Bonniers Konsthall, Sweden, 2009). ${ }^{11}$

Certain exhibitions manage to monitor the strategic capability of capitalism to absorb green rhetoric for economic interests or to appropriate and manipulate genetic and biological resources, such as Greenwashing: Environment, Perils, Promises, and Perplexities, ${ }^{12}$ Biopiracy, ${ }^{13}$ or Alter Natur. ${ }^{14}$ We could trace another segment of exhibitions that gather projects lying within the domain of the utopian, whose claims restore the capability of imagining alternative futures to the dystopian ones, like Brave New Worlds (Minneapolis: Walker Art Center, 2007) ${ }^{15} 0$ Futurs Abandonats. Demà ja Era la Qüestió (Fabra i Coats, Barcelona, 2014). ${ }^{16}$ The subject even became the central theme of international events such as the 9th Taipei Biennale entitled The Great Acceleration (Taipei Fine Arts Museum, 2015). ${ }^{17}$

Some of these concerns can be located in the projects of the artists that were included in the exhibition 7 MIL MILLONES ("Seven billion", referring to the average population of human beings inhabiting the earth) hosted at EACC (Espai d'Art Contemporani de Castelló), Castelló (País Valencià, Spain) in 2014. According to the curators David Arlandis and Javier Marroquí, the exhibition starts from the premise of "sustainable development" formulated by former Norwegian Prime Minister Gro Bruntland, whose utterances are quoted in the catalogue as the "development that meets the needs of the present without compromising the ability of future generations to meet their own needs". Published in 1987 in the frame of the United Nations World Commission on Environment and Development (WCED) and known as Our Common Future or Bruntland Report, Arlandis and Marroquí note that any political agenda or action plan had to be articulated or driven by the triangle of sustainability (economic, social and environmental) ever since.

They acknowledge that over time, "there has been a certain perversion of the uses of the expression due to the fact that it's been frequently reduced to its environmental aspect or to the relation between ecology and economy" and that "it is increasingly more evident that the current system is no longer capable of evolving positively in a local or global scale". For this reason they address the need for the rise of "new models of development which will have to show themselves more sustainable than the prevailing ones" (Arlandis, Marroquí, 2014, p. 6). As stated by the curators, these
Artistic Practices, Discursive Contexts and Environmental Humanities... models "will have to be necessarily based on a wider understanding of human activity, and will have to address life as a whole". In line with the postulates of Hardt and Negri's biopolitics, seven billion bodies simultaneously become territories for domination as well as resistance. They are subjects and starting points from which to "act, rehearse alternatives and propose distinct social forms" (Arlandis, Marroquí, 2014, p.12).

Among the projects displayed, we can highlight The Radiant, a video essay by the collective The Otolith group (2012) that investigates the aftermath of March 11, 2011, when the Tohoku earthquake triggered a tsunami that caused the collapse of the nuclear power plant Fukushima Daichii I in Japan, killing more than 15,000 people, injuring more than 3,000 and leaving 5,000 people missing. By combining historical documents such as film footage, television broadcasts and recordings of interviews with scientists, residents and activists, the film resurrects the promise of nuclear power that dominated the narratives after the Second World War. They bring it back to a present dominated by "necropolitics of radiation" and governmentality of death -as the collective say- thus interrogating it by provoking a critical dislocation in time and space.

Egyptian Chemistry by Ursula Biemann (2012) reflects on the role of the Nile river in the configuration of the economy and Egyptian society, addressing the profound impact in a molecular scale that caused the alteration of its course by hydraulic engineering projects and the use of synthetic fertilizers. These instances have added up to the rural activism regarding human forces that affect its complex ecologies, formed by a structure of organic, social, technological and chemical processes that account for the relations between vision, productivity, nature, engineering, resistance and revolution.

Exceeding Two Degrees is a project by Tue Greenfort previously featured in Sharjah Biennale, for which the artist negotiated with the institution the lowering $2^{\circ} \mathrm{C}$ of the building's heating system for the four months the exhibition was on. The resulting savings were invested in the reforestation of the Amazon through the acquisition of a parcel of land in collaboration with the Nepenthes organization. The decision of decreasing it by two degrees is related to the conclusions of the Stern Report (2006), which forecasted that if no effective action was taken regarding carbon dioxide emissions there would be a probability of $75 \%$ that global temperature would increase $2^{\circ} \mathrm{C}$ within the following 50 years.

10. Curated by Maja and Reuben Fowkes.

11. Curated by Sara Arrhenius.

12. Fondazione Sandretto Re Rebaudengo (Torino). Curators: llaria Bonacosa and Latitudes (Max Andrews and Mariana Cánepa).

13. Kunstraum Lakeside, Klangefurt (Austria), curated by Ines Doujak.

14. Z33, Hasselt (Belgium), curated by Karen Verschooren.

15. Curated by Doyrun Chong and Yasmil Raymond.

16. Curated by Martí Peran.

17. Curated by Nicholas Borriaud. 


\section{artnodes}

http://artnodes.uoc.edu

Defiende el Territorio desde el Aire ("Defending Territory from Air") is the title of the project for which the artist collective Basurama collaborated with local communities in the development of an aerial cartography which mapped the metabolism of the city of Castelló with the help of free-license tools provided by The Public Laboratory, a non-profit organization that develops and applies open-source tools to environmental exploration and investigation. Video-blog Radical Ecology and Tender Gardening by Johan Grimonprez tackles the notion of sustainability from the perspective of a wide social angle. Divided in 6 categories (Biotecture, Guerilla Gardening, Transition World, Radical Ecology, Off the Grid and Education), the project constitutes an online visual as well as textual archive hosted on YouTube that provides tools and materials for the development of political imagination.

Time / Bank by Julieta Aranda and Anton Vidokle proposes an alternative economic system managed by local communities based on an understanding of hours of work and skills as a bargaining chip. What is interesting about this barter system is that it arises from a social structure rather than an economic or financial society, it fosters the cultural value of a model that goes far beyond the capital, speculation, market value, commercial, rules, and avoids accumulation. The project formalizes itself as an installation and the establishment of a branch that aims to create a user's community that will interact with organizations with the same communal spirit.

Oficina de Rescate Invertido ("Inverted Rescue Office") by artist Núria Güell, is a project that helps citizens to recover the money evaded by banks or administrations through the articulation of small financial strategies such as how to organize if you are debtor with unaffordable mortgages, how to develop mechanisms of insubordination regarding VAT or how to declare yourself financially disobedient to make yourself insolvent. ${ }^{18}$ The free-advice provided at a consultation office available throughout the exhibition dates was given by an activist who worked in close collaboration with activists and local collectives. In a society deeply troubled by a systemic crisis - and not a crisis of the real economy - that condemned citizens to "poverty, to the impoverishment of life's conditions, to the dismantling of public services, to family instability, to the loss of future, to the consumption of anxiolytics and to the decadence of democracy"19 trough corruption and the pillaging of public wealth, this gesture aimed to guide citizens in reappropriating resources with the articulation of mechanisms that reproduce the 'social engineering' executed by the State and the Banking sector, but in this case applied towards them.

This project represents a shift from eco-criticism to eco-action through the instigation of radical mobilization (radical in terms of
Artistic Practices, Discursive Contexts and Environmental Humanities..

going back to the crux or the root of the problem) by exercising an active counter-narrative which is involved in the (re)construction or (re)storation of communities' basic conditions of life through methodologies of popular agency.

However, despite the alleged sustainable ethics 7 MIL MILLONES promotes, one could say there are certain inconsistencies in the curatorial approach that destabilizes its conceptual rigor. These basically come from three aspects. First and foremost, from a classical formulation of sustainable development they subscribe to, secondly, a particular image of a monumentalized humanity they picture, and thirdly, an omission of the practical, speculative and metaphoric dimensions of the projects and thus an omission of their consideration of artifacts for political imagination.

As the curators state, the projects "rehearse social, economic and environmental forms" they locate the curatorial statement at the centre of a triangular prism constrained by the economic, social and environmental sustainability outlined by the traditional notion of sustainable development. And from here emerges a risk of undermining the critical potential of the projects: in fact, curators omit that the needs the sustainable development notion is referring to, are economic needs of developed countries over developing ones. Similarly, curators have nothing to say about the environmental, social and political impact of the dependency of developed countries over the global south regarding the relatively recent displacement of industrial pollution from richer countries to the poorer ones.

On the other hand, this particular conception of the "Seven Billion" as the constituents of this "great scenario of production" of these worlds, visualizes the troupe of a mythical community: a notion of an inclusive collectivity, exempt from inequalities that parallel the very terminological vagueness that neoliberal politics relies on. Indeed, this idea is as naïve as the conception of nature as a pacifying and unifying entity, a conception which has been colonizing the collective consciousness as Bruno Latour notes (Latour, 2014, p. 20). This reference to the agency of a homogeneous, static, totalizing universal community resurrects the deceptive appeal of imperialistinflected "Earthrise" and "Blue Marble" extraterrestrial photographs of the earth taken by Apollo 8 (1968) and Apollo 17 (1972) mission, which were conceived to "chart the disappearance of the outside and to advocate for wilderness areas in the Global South as a cultural heritage of mankind" (Lekan, 2014, p. 171). ${ }^{20}$ This sense of a unity and global connectivity these photographs brought about, -which in the end were vivid representations of a great narrative- has now become obsolete.

18. See <http://www.nuriaguell.net/projects/33.html>

19. See <http://91.183.62.161:82/main/web_Radical_Ecology_home.html>.

20. The critical analysis of the rise of the image of "One Earth" and the ecological paradigm associated with it was explored by another major exhibition and publication entitled "The Whole Earth. California and the Disappearance of the Outside", curated and edited by Diedrich Diederichsen and Anselm Franke, a project that was developed in the framework of the "Anthropocene Project 2013-2014" at Haus der Kulturen der Welt. 


\section{artnodes}

http://artnodes.uoc.edu

In order to avoid this monopolizing approach exempt of differences, which is the product of this social engineering noted by Güell, will necessarily require an unravelling in the shades of meaning, revealing the ideology hidden in the very discourse of development, which is no other than the discourse of contemporary art. Formulating an alternative definition that links environmental with social, climatic, water justice that could demonstrate the mechanisms of capitalism and could (re)appropriate life "in all respects", should be the imperative of artistic, theoretical and curatorial practice, devoted to exploring the notions of ecology and environment in the present time.

Given the premise that infinite growth is not possible in a finiteresource planet, art and design can help us in imagining more resilient societies through the engendering of new models of individual resistance, collective alternatives and political decisions. In doing so, it turns a dystopian future into a speculative pragmatism that will shift from critique to proposition (Hlavajova, 2014). The main challenge of cultural institutions such as museums, that value objects will in turn, consist of giving them rich or broader historical, theoretical and critical context. Certainly, the new thinking constellation that the concept of the Anthropocene suggests, invites us first of all to widen or expand our notions of time and scale, but letting the practice of representation give way to the articulation of methodology in the course of unfolding our decisions.

\section{References}

ARLANDIS, D.; MARROQUÍ, J. (2014). 7 MIL MILLONES (ex. cat.). Espai d'Art Contemporani de Castelló.

<http://www.eacc.es/www/wp-content/ uploads/2014/02/7_000_000_000_CAS.pdf >

BATESON, G. (1972). Steps to an Ecology of Mind: Collected Essays in Anthropology, Psychiatry, Evolution and Epistemology. Chicago: University of Chicago Press.

BENNINSON, R.; ALOI, G. (2009). "In Conversation with Maja and Reuben Fowkes" (2009). Attenae, Iss. 10, Issn. 1756-9575. <http://www.antennae.org.uk/back-issues-2009/4583473838>

BOES, T. (2014). "Beyond Whole Earth: Planetary Mediation and the, Anthropocene". Environmental Humanities, vol. 5, p. 168. <http://environmentalhumanities.org/arch/vol5/5.9.pdf>

CORLETTE, R. T.; (2014). "The Anthropocene concept in ecology and conservation". Trends in Ecology and Evolution, Vol. 30, Iss. 1, pp. 36 - 41. <http://dx.doi.org/10.1016/j.tree.2014.10.007>

DEMOS, T. J. (2012). "Art After Nature: The Post-Natural Condition". Artforum, pp. 191-197;

DEMOS, T. J. (2013). "Contemporary Art and the Politics of Ecology". Third Text, no. 120, Vol. 26. <http://dx.doi.org/10.1080/095288 22.2013.753187>

DEMOS, T. J. (2014). "Gardens Beyond Eden: Bio-aesthetics, EcoFuturism, and Dystopia at dOCUMENTA (13)". Critical Cartography
Artistic Practices, Discursive Contexts and Environmental Humanities...

of Art and Visuality in the Global Age. In: Anna Maria GUASCH FERRER, Nasheli JIMÉNEZ DEL VAL (ed.). Newcastle: Cambridge Scholars Publishing, pp. 243-255.

DEMOS, T.J. (2009). "Politics of Sustainability: Art and Ecology”. Radical Nature: Art and Architecture for a Changing Planet 1969-2009 (ex. cat.). In: Francesco MANACORDA and Ariella YEDGAR (eds.). London: Barbican Art Gallery, pp. 17-30.

FOWKES, M.; FOWKES, R. (2010). "Reclaim Happiness: Art and Ecology Unbound". Artecontexto, no. 27/3, pp. 11-21.

FRANKE, A.; DIEDERICHSEN, D. (2013). The Whole Earth. California and the Disappearance of the Outside (ex. cat). Berlin: Sternberg Press.

GARRARD, G.; HANDWERK, G.; WILKE, S. (2014). "Imagining Anew: Challenges of Representing the Anthropocene". Environmental Humanities, vol. 5, pp. 149-153. <http://environmentalhumanities. org/arch/vol5/5.8. pdf>

GUATTARI, F. (1989). Les Trois Écologies. París: Gailée.

HLAVAJOVA, M. (2014). "And so We Participate". The Museum as a Workshop, Centraal Museum Utrecht. Future VocabulariesFuture Collections.

$<$ http://bak-utrecht.nl/en/Program/TheMuseumAsAWorkshop/An dSoWeParticipate?parent=Who\%2FMariaHlavajova $>$

LATOUR, B. (1999). Politiques de la Nature. Comment Faire Entrer les Sciences en Démocratie. Paris: La Découverte, [english edition: Politics of Nature. How to Bring Sciences into Democracy, Cambridge, Massachussets, London, Harvard University Press, 2004].

LATOUR, B. (2014). "Anthropocene Observatory". The Anthropocene Project. A Report. Haus der Kulturen der Welt (ed.), p. 20.

LEKAN, T. M., (2014). "Fractal Eaarth: Visualizing the Global Environment in the Anthropocene". Environmental Humanities, vol. 5, pp. 171-201. <http://environmentalhumanities.org/arch/ vol5/5.10.pdf><http://dx.doi.org/10.5751/ES-06192-190212>

MORSE, N., PELLISSIER, P. A., CIANCOLA [et al.] (2014) "Novel ecosystems in the Anthropocene: a revision of the novel ecosystem concept for pragmatic applications. Ecology and Society", vol. 19, no. 2, p. 12. <http://dx.doi.org/10.5751/es-06192-190212>

MORTON, T. (2004). Ecology Without Nature: Rethinking Environmental Aesthetics, London: Harvard University Press.

PALSSON, G.; SZERSZYNSKI, B.; SÖRLIN [et al.] (2013). "Reconceptualizing the 'Anthropos' in the Anthropocene: Integrating the Social Sciences and Humanities in Global Environmental Change Research". Environmental Science and Policy, Vol. 28, pp. 3-13. <http://dx.doi.org/10.1016/j. envsci.2012.11.004>

ROCKSTRÖM, J.; STEFFEN, W.; NOONE, K. [et al.] (2009). "Planetary Boundaries: Exploring the Safe Operating Space for Humanity". Ecology and Society, vol. 14, no. 2, art. 32. http://www.ecologyandsociety.org/vol14/iss2/art32/ 


\section{artnodes}

http://artnodes.uoc.edu

STEFFEN, W.; GRINEVALD, J.; CRUTZEN, P. [et al.] (2011). "The Anthropocene: Conceptual and Historical Perspectives". The Anthropocene: a new epoch of geological time? Volume 369, no. 1938, pp. 842-867. <http://dx.doi.org/10.1098/rsta.2010.0327> ZALASIEWICZ, J.; WILLIAMS, M.; FORTEY, R. [et al.] (2011). "Stratigraphy of the Anthropocene". The Anthropocene: a new epoch of geological time?. Volume 369, no. 1938, pp. 1036-1055. $<$ http://rsta.royalsocietypublishing.org/content/ roypta/369/1938/1036.full.pdf>
Artistic Practices, Discursive Contexts and Environmental Humanities..

ZALASIEWICZ, J.; WILLIAMS, M.; HAYWOOD, A. [et al.] (2011). The Anthropocene: a new epoch of geological time? Phil. Trans. R. Soc. A. London: Royal Society Publishing, vol. 369, no. 1938. $<$ http://dx.doi.org/10.1098/rsta.2010.0315>

\section{Recommended citation}

ALONSO, Christian M. (2015). "Artistic Practices, Discursive Contexts and Environmental Humanities in the Age of the Anthropocene" In: Pau ALSINA and Ana RODRÍGUEZ GRANELL (cord) "Art Matters". Artnodes. No. 15, pp. 81-89. UOC [Accessed: dd/mm/yy].

$<$ http://journals.uoc.edu/ojs/index.php/artnodes/article/view/n15-alonso/n15-alonso-pdf-en> $<$ http://dx.doi.org/10.7238/a.v0i15.2579>

This article is - unless indicated otherwise - covered by the Creative Commons Spain Attribution 3.0 licence. You may copy, distribute, transmit and adapt the work, provided you attribute it (authorship, journal name, publisher) in the manner specified by the author(s) or licensor(s). The full text of the licence can be consulted here: http://creativecommons.org/licenses/by/3.0/es/deed.en. 


\section{artnodes}

http://artnodes.uoc.edu

Artistic Practices, Discursive Contexts and Environmental Humanities...

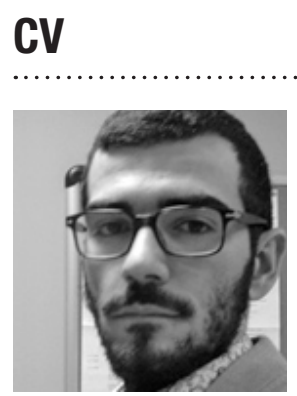

\section{Christian Alonso}

http://orcid.org/0000-0001-8639-9398

Research group Art Globalization Interculturality (AGI)

Department of Art History

University of Barcelona

chrmaal@gmail.com

PhD Associated Researcher at the Research Group AGI (Art Globalization Interculturality), University of Barcelona, where he develops a thesis on the role of artistic practice in the conformation, analysis and crtitical response to the age of Anthropocene. The research, directed by Anna Maria Guasch, is recognized for the Spanish Government through a Predoctoral Scholarship given by the Ministry of Economy and Competitiveness.

Christian holds a BA in Art History by the University of Barcelona and the Universiteit van Amsterdam (2012). In 2013 he graduated from a Master Degree in Advanced Studies in Art History at the University of Barcelona with the final project The Artistic Practice to the Post-Natural Condition of Society. Art and Ecology. Since 2008 he has focused his interest in visual studies, curatorship and analysis of the artistic practices from World War II. He is the coordinator of the training seminar ON MEDIATION: Theory and Curatorial Practices in the Global Art, and was appointed member of the mediation team of Sala d'Art Jove 2015 (Barcelona).

Christian is artistic director and curator of the ongoing video-essay cycle Documentary Pactices in the Age of Neoliberal Globalization: Aesthetics and Politics, hosted at CFD (Centre de Fotografia i Mitjans Documentals, Barcelona) and was member of the curatorial team of the group shows Tedium Vitae (ADN Platform, May-October 2015) and Barcelona inspira (Cercle Artístic Sant Lluc, May 2014). He is co-curator of several self-managed projects such as Perder el Norte, [Tentativa \#3], and COMPARTIMENTS together with Col-lectiu NIO. Christian participated in the group exhibition ¿Qué hacemos con la Performance? ¿Qué hacemos con la Performatividad? (DAFO and Centre d'Art La Panera, Lleida, October 2014) as a result of the workshop given by Cabello/Carceller in the frame of the visual arts support program directed by Jordi Antas.

Departament d'Història de l'Art Universitat de Barcelona

Facultat de Geografia i Història

Montalegre, 6

08001 Barcelona

\section{$\square$ UOC \\ Universitat Oberta de Catalunya}

